\title{
Septic shock non-thyroidal illness syndrome causes hypothyroidism and conditions for reduced sensitivity to thyroid hormone
}

\author{
Isabel Castro ${ }^{1, *}$, Leah Quisenberry ${ }^{2, *}$, Rosa-Maria Calvo ${ }^{3}$, Maria-Jesus Obregon ${ }^{3}$ \\ and Joaquin Lado-Abeal ${ }^{1,2,4}$
}

${ }^{1}$ Division of Endocrinology, Department of Internal Medicine ${ }^{2}$ Department of Cell Biology and Biochemistry, Texas Tech University Health Sciences Center School of Medicine, 3601 4th Street STOP 9410, Lubbock, Texas 79430-9410, USA ${ }^{3}$ Instituto de Investigaciones Biomédicas Alberto Sols, Consejo Superior de Investigaciones Científicas, Madrid, Spain ${ }^{4}$ Unidade de Enfermedades Metabólicas e Tiroideas (UETeM), Facultad de Medicina, Universidad de Santiago, Santiago de Compostela, Spain

*(I Castro and L Quisenberry contributed equally to this work and should be given equal consideration.)

Correspondence should be addressed to J Lado-Abeal Email joaquin.lado@ttuhsc.edu

\begin{abstract}
Non-thyroidal illness syndrome (NTIS) is part of the neuroendocrine response to stress, but the significance of this syndrome remains uncertain. The aim of this study was to investigate the effect of lipopolysaccharide (LPS)-induced NTIS on thyroid hormone (TH) levels and TH molecular targets, as well as the relationship between septic shock nuclear factor kappa-light-chain-enhancer of activated B cells (NF-kB) activation and TH receptor $\beta$ (THRB) gene expression at a multi-tissue level in a pig model. Prepubertal domestic pigs were given i.v. saline or LPS for $48 \mathrm{~h}$. Serum and tissue TH was measured by chemiluminescence and RIA. Expression of THRs and cofactors was measured by real-time PCR, and deiodinase (DIO) activity was measured by enzyme assays. Tissue NF-kB nuclear binding activity was evaluated by EMSA. LPS-treated pigs had decreased TH levels in serum and most tissues. DIO1 expression in liver and kidney and DIO1 activity in kidney decreased after LPS. No changes in DIO2 activity were observed between groups. LPS induced an increase in hypothalamus, thyroid, and liver DIO3 activity. Among the other studied genes, monocarboxylate transporter 8 and THRB were the most commonly repressed in endotoxemic pigs. LPS-induced NF-kB activation was associated with a decrease in THRB gene expression only in frontal lobe, adrenal gland, and kidney cortex. We conclude that LPS-induced NTIS in pigs is characterized by hypothyroidism and tissue-specific reduced TH sensitivity. The role of NF-kB in regulating THRB expression during endotoxemia, if any, is restricted to a limited number of tissues.
\end{abstract}
Key Words
- non-thyroidal illness syndrome
- septic shock
$\checkmark$ deiodinases
- thyroid hormone receptors

\section{Introduction}

Non-thyroidal illness syndrome (NTIS) is a component of the neuroendocrine and metabolic response to severe stress and starvation, characterized by low serum triiodothyronine $\left(\mathrm{T}_{3}\right)$ and inappropriately normal or low
$\mathrm{TSH}$; in severe cases, serum $\mathrm{rT}_{3}$ increases and thyroxine $\left(\mathrm{T}_{4}\right.$ ) decreases (Wartofsky \& Burman 1982, DeGroot 1999). As thyroid hormone (TH) increases energy expenditure (Silva 2006), NTIS can be considered an adaptive response

Published by Bioscientifica Ltd.
Journal of Molecular

Endocrinology

(2013) 50, 255-266 
to counteract catabolism during fasting and illness (Wartofsky \& Burman 1982, DeGroot 1999, Boelen et al. 2011). However, during prolonged illness, it is unclear whether NTIS is beneficial (DeGroot 2003, Stathatos \& Wartofsky 2003) and, in fact, patients with low serum $\mathrm{T}_{4}$ have an increased probability of death (Slag et al. 1981).

NTIS results from a central hypothyroidism together with tissue-specific changes resembling consumptive hypothyroidism and reduced sensitivity to $\mathrm{TH}$ action. Studies on humans have shown that central hypothyroidism in NTIS is a consequence of decreased expression of TRH mRNA in the hypothalamus (Fliers et al. 1997, Van den Berghe et al. 1998). Also, studies on humans have shown a tissue-specific increase in type 3 deiodinase (DIO3) activity (Rodriguez-Perez et al. 2008), like that observed in consumptive hypothyroidism, which, combined with decreased activity of type 1 deiodinase (DIO1; Peeters et al. 2003, Debaveye et al. 2005), results in inactivation of $\mathrm{T}_{4}$ into $\mathrm{rT}_{3}$ and reduced synthesis and increased degradation of $\mathrm{T}_{3}$. In both humans and rodents, NTIS is associated with decreased expression of $\mathrm{TH}$ receptors (THRs) and their nuclear partners retinoid $\mathrm{X}$ receptors $(R X R)$ in some tissues (Beigneux et al. 2003, Feingold et al. 2004, Rodriguez-Perez et al. 2008, Boelen et al. 2011), which may create a situation of reduced sensitivity to the action of $\mathrm{TH}$, the relevance of which has not yet been explored.

The molecular mechanisms at the root of NTIS have yet to be characterized. In rodents, the fasting-related increase in DIO3 activity may be a consequence of low leptin levels (Boelen et al. 2012), and leptin prevents starvation-related central hypothyroidism (Legradi et al. 1997). High levels of pro-inflammatory cytokines, as observed during moderate-to-severe illness (RodriguezPerez et al. 2008), block the synthesis and release of TRH and TSH (van Haasteren et al. 1994) and decrease DIO1 activity (Jakobs et al. 2002), an effect involving nuclear factor kappa-light-chain-enhancer of activated B cells (NF-kB) activation (Nagaya et al. 2000) and a competition for limiting amounts of nuclear receptor co-activator 1 between the DIO1 promoter and the promoters of cytokine-induced genes (Yu \& Koenig 2000). TH increases expression and activity of DIO1, and as the fasting-related decrease in DIO1 activity in rodents is restored by $\mathrm{TH}$ replacement, it is believed that low $\mathrm{T}_{3}$ levels during NTIS are responsible for and not the consequence of this decrease (O'Mara et al. 1993, Boelen et al. 2012). THRs also decrease during starvation and illness. Although mechanisms responsible for inhibition of THR expression during fasting remain unknown, NF-kB activation has been suggested to be responsible for the decrease in $\mathrm{TH}$ receptor $\beta 1$ (THRB1) expression during inflammation in rodents (Kwakkel et al. 2006).

Limited access to human tissues is an obstacle for understanding the effects of NTIS on patients and uncovering the molecular mechanisms involved in NTIS. Restrictions inherent to human research can be resolved in part by establishing large animal models of NTIS. Domestic pigs are readily available and affordable large animals that have been proven to be a useful model for human TH metabolism (Wassen et al. 2004). Our aim was to investigate in pigs the effects of lipopolysaccharide (LPS)-induced septic shock NTIS on i) TH levels in serum and tissues, ii) changes in gene expression of TH molecular targets and iodothyronine DIOs as well as on the activity of DIO enzymes at a multi-tissue level, and iii) NF-kB nuclear binding activity and its correlation with the tissue-specific decrease in THRB gene expression observed during endotoxemia.

\section{Materials and methods}

\section{Animals}

The study was approved by Texas Tech University Institutional Animal Care and Use Committee. Seventeen prepubertal female pigs (Sus scrofa domesticus) weighing 9-11 kg were randomly assigned to control $(n=8)$ or LPS-treated $(n=9)$ groups. Pigs were housed under controlled temperature $\left(22 \pm 2{ }^{\circ} \mathrm{C}\right)$, humidity $(55 \pm 5 \%)$, and light-dark cycling (on 0700-1900 h, off 1900-0700 h).

Forty-eight hours before the infusion period, two catheters were placed into jugular veins through a neck incision under light sedation, subcutaneously passed to the back of the neck, and heparinized to maintain patency. Catheters were used for blood sampling and continuous infusion of saline or LPS.

Experiments were always performed in pairs (control vs LPS), one pig per individual pen under freely moving conditions for $48 \mathrm{~h}$, starting at $0800 \mathrm{~h}$ of day 1 . The animals were continuously monitored by the personnel involved in the study. Control group pigs received continuous i.v. normal saline infusion. LPS-treated pigs received endotoxin (Escherichia coli 0111:B4, Sigma-Aldrich) infusion as follows: a 5 -min bolus of $3.5 \mu \mathrm{g} / \mathrm{kg}$ per min followed by a continuous infusion of $3.5 \mu \mathrm{g} / \mathrm{kg}$ per h during the first $12 \mathrm{~h}$. At $2000 \mathrm{~h}$, if the body temperature increased more than $2{ }^{\circ} \mathrm{C}$ over pre-infusion temperature, the infusion rate was not changed; however, if the body temperature was lower than $2{ }^{\circ} \mathrm{C}$ over pre-infusion temperature, LPS infusion was

Published by Bioscientifica Ltd. 
increased with a 5 -min bolus of $4 \mu \mathrm{g} / \mathrm{kg}$ per min followed by a continuous infusion of $4 \mu \mathrm{g} / \mathrm{kg}$ per h during the next $12 \mathrm{~h}$. At day 2, $0800 \mathrm{~h}$, changes in infusion rate followed the same requirements, but if needed, LPS was increased with a 5 -min bolus of $5 \mu \mathrm{g} / \mathrm{kg}$ per min followed by a continuous infusion of $5 \mu \mathrm{g} / \mathrm{kg}$ per h until day 3, $0800 \mathrm{~h}$. Heart rate and skin temperature were continuously monitored with a Jacketed External Telemetry system (Data Sciences International, St Paul, MN, USA) attached to skin and protected by an in-house made jacket. Food and water were available ad libitum. Food intake was estimated by weighing the food in the animal pen at the beginning of the infusion period and at necropsy; if an animal died before $48 \mathrm{~h}$, food in the pen was weighed and compared with its pair at the time of death. Presence of food in the animal's stomach was recorded at necropsy.

At the end of the infusion period, animals were killed by i.v. pentobarbital sodium (Fatal-Plus, Vortech Pharmaceuticals, Dearborn, MI, USA). Tissue samples were taken immediately after death from cerebral frontal lobe, cerebellum, hypothalamus, pituitary gland, thyroid gland, lung, heart left ventricle, liver, spleen, duodenum, ascendant colon, adrenal gland, and skeletal muscle (quadriceps femoris). Tissue samples were immediately frozen in liquid nitrogen and stored at $-80^{\circ} \mathrm{C}$ until further analysis.

\section{Hormonal studies}

Serum hormonal levels were measured in blood samples obtained immediately before infusion began and at the end of the infusion period. Chemiluminescence was used to measure serum-free $\mathrm{T}_{4}\left(\mathrm{FT}_{4}\right)$, free $\mathrm{T}_{3}\left(\mathrm{FT}_{3}\right)$ (ADVIA Centaur, Bayer Diagnostics), and cortisol (Immulite 2000, DPC, Gwynedd, UK). Serum $\mathrm{rT}_{3}$ was measured by RIA (Alpco Diagnosis, Salem, NH, USA).

$\mathrm{T}_{4}$ and $\mathrm{T}_{3}$ levels were measured in frontal lobe, lung, heart left ventricle, liver, kidney cortex, and skeletal muscle by in-house RIAs after extraction and purification of tissue samples (Morreale de Escobar et al. 1985, Calvo et al. 1997). Frozen tissue samples (100-150 mg) were homogenized in methanol with tracer amounts of $\left[{ }^{131} \mathrm{I}\right]-\mathrm{T}_{4}$ and $\left[{ }^{125} \mathrm{I}\right]-\mathrm{T}_{3}$ added to each homogenate. The iodothyronines were extracted using chloroform-methanol (2:1), back-extracted into an aqueous phase, and purified through Bio-Rad AG 1X2 resin columns (Bio-Rad Laboratories S.A.) using a $\mathrm{pH}$ gradient. The acetic extracts were then evaporated to dryness and dissolved in RIA buffer. Each extract was counted to determine the recovery of $\left[{ }^{131} \mathrm{I}\right]-\mathrm{T}_{4}$ and $\left[{ }^{125} \mathrm{I}\right]-\mathrm{T}_{3}$ in each sample. The samples were submitted to highly sensitive RIA for the determination of $\mathrm{T}_{4}$ and $\mathrm{T}_{3}$, the limits of sensitivity being $2.5 \mathrm{pg} \mathrm{T}_{4}$ and $1.5 \mathrm{pg} \mathrm{T}_{3}$ /tube. Each sample was processed in duplicate. Concentrations are calculated using the amounts of $\mathrm{T}_{4}$ and $\mathrm{T}_{3}$ found in the RIAs, the individual recovery of the $\left[{ }^{131} \mathrm{I}\right]-\mathrm{T}_{4}$ and $\left[{ }^{125} \mathrm{I}\right]-\mathrm{T}_{3}$ added to each sample, and the weight of the tissue sample extracted. Cross-reactivity of both RIAs has been previously reported (Ruiz de Oña et al. 1991).

High specific activity $\left[{ }^{131} \mathrm{I}\right]-\mathrm{T}_{4},\left[{ }^{125} \mathrm{I}\right]-\mathrm{T}_{3}$, and $\left[{ }^{125} \mathrm{I}\right]-\mathrm{T}_{4}$ $(\geq 3000 \mu \mathrm{Ci} / \mu \mathrm{g}$ ) were synthesized in our laboratory as described previously (Morreale de Escobar et al. 1985) and used for the in-house RIAs and as recovery tracers for tissue extractions.

\section{Gene expression analysis by quantitative real-time PCR}

Total RNA was extracted from tissue and reverse transcribed as described previously (Rodriguez-Perez et al. 2008). Expression of THRB, TH receptor $\alpha 1$ (THRA1), TH receptor $\alpha 2$ (THRA2), retinoid $\mathrm{X}$ receptor $\alpha$ $(R X R A)$, retinoid $X$ receptor $\beta(R X R B)$, nuclear receptor co-repressor 1 (NCOR1), monocarboxylate transporter 8 or SLC16A2 (MCT8), type I iodothyronine DIO (DIO1), type II iodothyronine DIO (DIO2), v-rel reticuloendotheliosis viral oncogene homolog A (avian) nuclear factor NF-kappa-B p65 subunit (RELA), and of the internal control ribosomal protein L4 gene (RPL4) genes were quantified by real-time PCR in an Applied Biosystems 7500 instrument (Applied Biosystems) using $\mathrm{RT}^{2} \mathrm{SYBR}$ Green ROX FAST master mix (Qiagen Sciences) and specific oligonucleotide primers (sequences are available upon request). The reaction mixtures contained $5 \mu \mathrm{l}$ $\mathrm{RT}^{2}$ SYBR Green ROX FAST master mix, $4.2 \mu \mathrm{l} \mathrm{ddH}_{2} \mathrm{O}$, $1.0 \mu \mathrm{l}$ template cDNA (up to $250 \mathrm{ng}$ ), and $0.4 \mu \mathrm{l}$ genespecific $10 \mu \mathrm{M}$ PCR oligonucleotides primers. The reaction conditions were $95^{\circ} \mathrm{C}$ for $10 \mathrm{~min}$, followed by 40 cycles of $95^{\circ} \mathrm{C}$ for $20 \mathrm{~s}$ and $60^{\circ} \mathrm{C}$ for $30 \mathrm{~s}$. Relative gene expression was calculated as $\Delta \mathrm{Ct}$ (the difference between the cycle threshold values, $C \mathrm{t}$, of the internal control, RPL4, and $C t$ of gene of interest) and confirmed by $2^{-\Delta \Delta} C t$ method (Livak \& Schmittgen 2011). Interassay variability was corrected by measuring RNA polymerase II $\mathrm{Ct}$ in the same cDNA batch obtained from HepG2 cells.

\section{DIOs activity}

DIO1 and DIO2 activities were assayed in tissue sample homogenates prepared in $0.1 \mathrm{M}$ potassium phosphate, $2 \mathrm{mM}$ EDTA, and $2 \mathrm{mM}$ dithiothreitol (DTT), pH 7.0.

Published by Bioscientifica Ltd. 
The same conditions were used for DIO3 activity except DTT was changed to $10 \mathrm{mM}$. Protein concentration was determined by Bradford's method using BSA as a standard. Tissue samples were assayed in duplicates.

DIO1 activity was measured using $25-50 \mu \mathrm{g}$ protein in $100 \mu$ reaction mixture, $\left[{ }^{125} \mathrm{I}\right]-\mathrm{rT}_{3}$ (100 000 c.p.m./tube), $400 \mathrm{nM} \mathrm{rT}_{3}$, and $2 \mathrm{mM}$ DTT. Incubation was carried at $37^{\circ} \mathrm{C}$ for $1 \mathrm{~h}$, with or without $1 \mathrm{mM}$ propylthiouracil (PTU). Results are expressed in $\mathrm{pmol} / \mathrm{min}$ per $\mathrm{mg}$ protein.

DIO2 activity was measured using $50 \mu \mathrm{g}$ protein in $100 \mu \mathrm{l}$ reaction mixture consisting of $\left[{ }^{125} \mathrm{I}\right]-\mathrm{T}_{4}$ (200 000 c.p.m./tube), $2 \mathrm{nM} \mathrm{T}_{4}$ or $500 \mathrm{nM} \mathrm{T}_{4}$ (to inhibit DIO2 activity), $1 \mu \mathrm{M} \mathrm{T} \mathrm{T}_{3}$ (to inhibit DIO3 activity), $20 \mathrm{mM}$ DTT, and $1 \mathrm{mM}$ PTU for $2 \mathrm{~h}$ at $37^{\circ} \mathrm{C}$. Results are expressed in $\mathrm{fmol} / \mathrm{min}$ per $\mathrm{mg}$ protein. DIO3 activity was assayed using $50-100 \mu \mathrm{g}$ protein in $100 \mu \mathrm{l}$ reaction mixture, $\left[{ }^{125} \mathrm{I}\right]-\mathrm{T}_{3}$ (200000 c.p.m./tube), $1 \mathrm{nM} \mathrm{T}_{3}$, or $1 \mu \mathrm{M} \mathrm{T}_{3}$ (to inhibit DIO3 activity), at $37^{\circ} \mathrm{C}$ for $2 \mathrm{~h}$. Results are expressed in $\mathrm{fmol} / \mathrm{min}$ per $\mathrm{mg}$ protein.

Before each assay, $\left[{ }^{125} \mathrm{I}\right]-\mathrm{T}_{4},\left[{ }^{125} \mathrm{I}\right]-\mathrm{T}_{3}$, and $\left[{ }^{125} \mathrm{I}\right]-\mathrm{rT}_{3}$ (Perkin Elmer, Billerica, MA, USA) were purified by dialysis as described previously (Dumitrescu et al. 2005).

For DIO1 and DIO2 activity assays, reactions were stopped by adding $100 \mu \mathrm{l}$ of cold $2 \%$ BSA and $800 \mu \mathrm{l}$ of $10 \%$ trichloroacetic acid. After centrifugation at $2053 \boldsymbol{g}$ for $10 \mathrm{~min}, 800 \mu \mathrm{l}$ supernatant was applied to AG $50 \mathrm{~W}-\mathrm{X} 2$ columns (bed volume $=1 \mathrm{ml}$ ) (Bio-Rad Laboratories) and eluted with $10 \%$ glacial acetic acid. The $\left[{ }^{125} \mathrm{I}\right]$ generated in the assay was counted in a gamma scintillation counter (Packard Cobra Gamma Counter, Perkin Elmer, Waltham, MA, USA). For DIO3 activity assay, reactions were stopped by adding $100 \mu \mathrm{l}$ cold methanol. After centrifugation, $150 \mu \mathrm{l}$ supernatant was applied to a $250 \times 4.6 \mathrm{~mm}$ ID, $5 \mu \mathrm{m}$ Viva C18 analytical column (Restek Corporation, Bellefonte, PA, USA) connected to a HPXL system (Rainin Instruments, Woburn, MA, USA) and eluted isocratically with a mixture of methanol and $\mathrm{H}_{2} \mathrm{O}$ (55:45), $\mathrm{pH}$ 3.0, at a flow of $1 \mathrm{ml} / \mathrm{min}$. Fractions of $0.3 \mathrm{~min}$ were collected and counted for radioactivity.

Blanks were performed in quadruplicates by substituting tissue homogenates for buffer homogenates. Assay detection limit was calculated as the average of $\left[{ }^{125} \mathrm{I}^{-}\right]$ (DIO1 and DIO2 assay) or $\left[{ }^{125} \mathrm{I}\right]-\mathrm{T}_{2}$ (DIO3 assay) produced by blanks multiplied by 3.3 times SD.

\section{NF-kB nuclear binding activity}

EMSA was used to investigate NF-kB nuclear binding activity in samples obtained from frontal lobe, cerebellum, heart left ventricle, lung, liver, kidney cortex, spleen, adrenal gland, and skeletal muscle of six control and six LPS-treated pigs. NF-kB binding activity was correlated with THRB gene expression in these tissues.

Nuclear protein was extracted using a nuclear extraction kit (Signosis, Inc., Sunnyvale, CA, USA) and protein concentration was determined by Bradford's method. Oligonucleotides containing a consensus binding site for NF-kB (5'-AGTTGAGGGGACTTTCCCAGGC-3') or mutated binding site (5'-AGTTGAATTCACTTTCCCAGGC-3') were annealed, end-labeled using T4 polynucleotide kinase (New England BioLabs, Ipswich, MA, USA) and $\gamma^{32}$ P-ATP $(3000 \mathrm{Ci} / \mathrm{mmol}$ at $10 \mathrm{mCi} / \mathrm{ml}$, Perkin Elmer), and separated from unincorporated nucleotides over a Sephadex G-50 column (Illustra ProbeQuant, GE Healthcare, Piscataway, NJ, USA). Nuclear extracts $(10 \mu \mathrm{g})$ were incubated with labeled consensus or mutated probes in a binding reaction buffer $\left(5 \mathrm{mM} \mathrm{MgCl}_{2}\right.$, $2.5 \mathrm{mM}$ EDTA, $2.5 \mathrm{mM}$ DTT, $250 \mathrm{mM} \mathrm{NaCl}, 50 \mathrm{mM}$ Tris-HCl, pH 7.5, 20\% glycerol, $0.25 \mathrm{mg} / \mathrm{ml}$ poly(dI-dC)) for $20 \mathrm{~min}$ at room temperature. In competition studies, 100 -fold molar excess of unlabeled mutant oligonucleotide was added to the binding reaction in addition to labeled probe. The protein-DNA complexes were resolved on a non-denaturing $6 \%$ polyacrylamide gel in $0.5 \mathrm{X}$ TBE buffer. The gel was run at $250 \mathrm{~V}$ for $2 \mathrm{~h}$, dried, and exposed to autoradiography film at $-80^{\circ} \mathrm{C}$. For supershift assays, $0.4 \mu \mathrm{g}$ antibody against p50 (sc114) or p65 (sc-109; Santa Cruz Biotechnology) NF-kB subunits was added to the reaction buffer for $20 \mathrm{~min}$ at room temperature before addition of poly $(\mathrm{dI}-\mathrm{dC})$ and $\gamma^{32}$ P-labeled probe.

Activated NF-kB-positive control was obtained from TNF $\boldsymbol{\alpha}$-stimulated HepG2 cells. Briefly, HepG2 cells were incubated as described previously (Lado-Abeal et al. 2005); at 70\% confluence, medium was removed and cells were grown in serum-free Eagle's minimum essential medium for $24 \mathrm{~h}$ before treatment with TNF $\alpha(50 \mathrm{ng} / \mathrm{ml})$ (Sigma) for $30 \mathrm{~min}$. HepG2 cells were harvested to obtain nuclear extracts used for EMSA as described earlier.

\section{Statistical analysis}

Data were analyzed using GraphPad Prism (GraphPad Software, Inc., La Jolla, CA, USA). Gaussian distribution of variables was checked by Kolmogorov-Smirnov test. Results are expressed as mean \pm s.D. or as Tukey boxand-whisker plot. Student's $t$-test or Mann-Whitney $U$ test were used for same variable comparison between groups when appropriate.

Published by Bioscientifica Ltd. 


\section{Results}

LPS administration caused high mortality. Of the nine pigs treated with LPS, three pigs survived the 48-h LPS infusion period, one pig died at $12 \mathrm{~h}$, and three pigs died between 6 and $8 \mathrm{~h}$ from the beginning of LPS infusion. Two pigs died in the first $4-5 \mathrm{~h}$ and were excluded from the statistical analysis. All control pigs survived the 48-h period of saline infusion.

LPS infusion increased skin temperature by more than $0.5^{\circ} \mathrm{C}$ in the first $1-3 \mathrm{~h}$. Elevated temperature was sustained in four animals. Hypothermia occurred in five pigs after the initial raise in body temperature, and all these animals died within $48 \mathrm{~h}$. Food was always present in animal stomach at necropsy. Control pigs consumed $4.42 \pm 0.52 \mathrm{~kg}$ of food, while LPS-treated pigs that survived the $48 \mathrm{~h}$ consumed $0.24 \pm 0.11 \mathrm{~kg}$.

\section{Effect of LPS on serum and tissue hormonal levels}

LPS infusion $(n=7)$ caused a decrease in serum $\mathrm{FT}_{4}$ and $\mathrm{FT}_{3}$ and an increase in serum cortisol compared with control $(n=8)$ (Fig. 1). No differences were observed in serum $\mathrm{rT}_{3}$ levels. However, in LPS-treated pigs, the $\mathrm{rT}_{3} / \mathrm{FT}_{4}$ ratio was threefold higher at the end of the infusion compared with pre-infusion values $(0.30 \pm 0.06$ pre-LPS vs $0.92 \pm 0.30$ post-LPS, $P<0.05)$. LPS-treated pigs had significantly lower $\mathrm{T}_{4}$ and $\mathrm{T}_{3}$ levels in most analyzed tissues, except for $\mathrm{T}_{4}$ in lung and $\mathrm{T}_{3}$ in brain (Fig. 1).

\section{DIOs gene expression and activity}

DIO1 mRNA expression was detected in all tissues from the control group, while DIO1 activity was detected only in liver and kidney cortex and medulla, the two organs with the highest DIO1 mRNA expression levels (Fig. 2). LPS decreased DIO1 mRNA expression in liver and kidney as well as DIO1 activity in kidney cortex. Although DIO1 activity tended to decrease in liver and kidney medulla of LPS-treated pigs, the decrease did not achieve statistical significance (Fig. 2).

DIO2 mRNA expression was detected in all control tissues. The highest expression was detected in frontal lobe, hypothalamus, pituitary gland, liver, and skeletal muscle. LPS infusion was associated with increased DIO2 mRNA expression in kidney cortex and decreased expression in liver. DIO2 activity was detected in control hypothalamus, pituitary gland, and thyroid gland, and LPS did not change enzyme activity in the hypothalamus (median: 0.22 (range: $0-0.56$ ) fmol/mg per min control vs
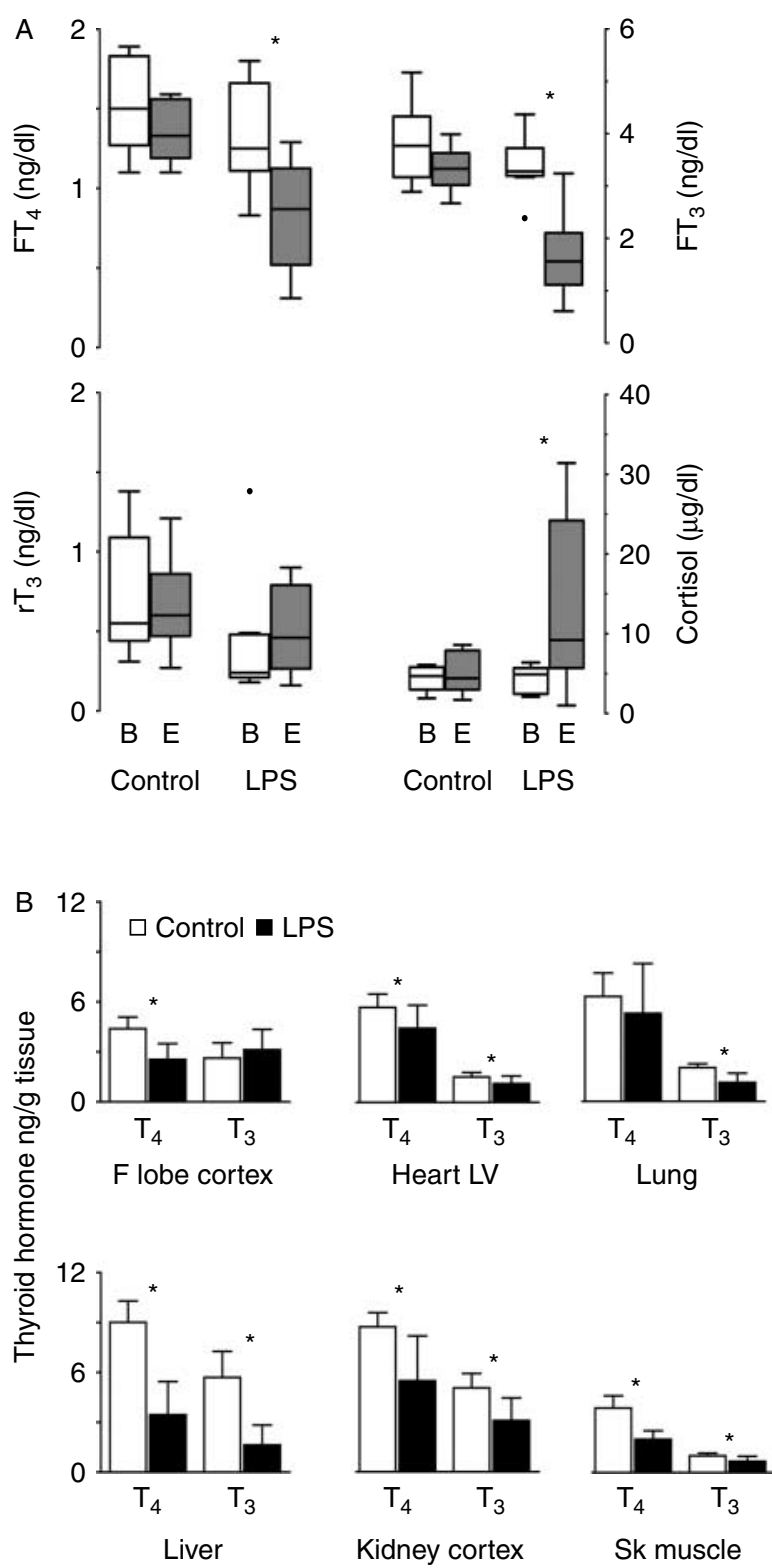

Heart LV

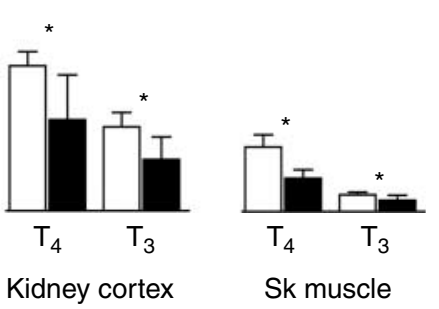

Figure 1

(A) Serum levels of thyroid hormones and cortisol in pigs. Basal (B) levels of serum-free $T_{4}\left(\mathrm{FT}_{4}\right), \mathrm{FT}_{3}, \mathrm{rT}_{3}$, and cortisol were not significantly different between control ( $n: 8)$ and LPS-treated ( $n: 9)$ pigs. In LPS-treated pigs, serum $\mathrm{FT}_{4}$ and $\mathrm{FT}_{3}$ decreased and cortisol increased at the end $(\mathrm{E})$ of the infusion period. Hormonal values are represented with Tukey box-and-whisker plot. (B) $T_{4}$ and $T_{3}$ levels in tissues from control $(n: 8)$ and LPS-treated $(n: 9)$ pigs. Values are represented as mean \pm s.D. ( ${ }^{*} P<0.05$; closed circle, outlier value).

$0.23(0-0.66) \mathrm{fmol} / \mathrm{mg}$ per min LPS, NS), pituitary gland (median: $0.58(0-2.85) \mathrm{fmol} / \mathrm{mg}$ per min control vs 0.51 $(0-3.19) \mathrm{fmol} / \mathrm{mg}$ per min LPS, NS), or thyroid gland (median: $0.08(0-0.34) \mathrm{fmol} / \mathrm{mg}$ per min control vs $0.09(0-0.23) \mathrm{fmol} / \mathrm{mg}$ per min LPS, NS). 


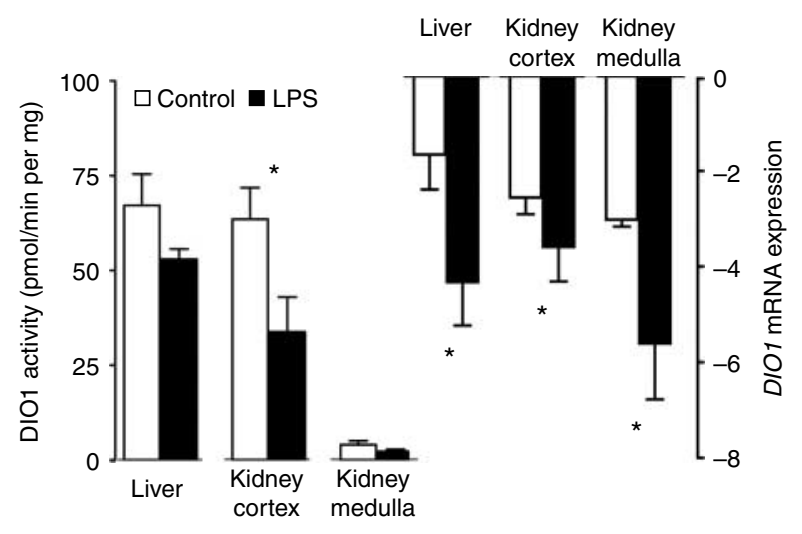

Figure 2

DIO1 activity (left) and relative gene expression (right) in liver and kidney cortex and medulla. DIO1 gene relative expression is represented as $\Delta C \mathrm{Ct}$. A $\Delta C \mathrm{Ct}$ difference of 1 indicates a twofold difference in gene expression. LPS induced a significant decrease in DIO1 gene expression in liver and kidney and in DIO1 activity in kidney cortex. The decrease in DIO1 activity observed in liver did not achieve statistical significance. Values are represented as mean \pm s.D. $(* P<0.05)$.

DIO3 activity was detected in all analyzed tissues except in heart left ventricle and spleen, although important differences between tissues were noticed (Fig. 3). LPS-treated pigs showed a remarkable increase in liver DIO3 activity, and a significant increase was also observed in the hypothalamus and thyroid gland (Fig. 3).

\section{MCT8, THRs, and THR cofactor gene expression}

MCT8, THR, and THR cofactor mRNA expression showed remarkable differences between tissues. THRB, THRA1, and THRA2 mRNA expression in control pig tissues are shown in Fig. 4.

LPS effects on MCT8, THRB, THRA1, THRA2, RXRA, and RXRB mRNA expression are shown in Fig. 5. In cerebellum, hypothalamus, thyroid gland, duodenum, colon, spleen, and skeletal muscle, expression of these genes was not significantly different between control and LPS-treated pigs. NCOR1 mRNA expression did not differ between groups in any of the studied tissues.

\section{NF-kB nuclear binding activity}

NF-kB p50-p65 nuclear binding was detected in all studied tissues except in cerebellum and skeletal muscle in both control and LPS-treated animals. LPS induced an increase in NF-kB nuclear binding activity in frontal lobe, lung, kidney cortex, and adrenal gland (Fig. 6A). No differences between groups were found in heart left ventricle, liver, or spleen (Fig. 6A). Tissues RELA mRNA expression did not change significantly after LPS. NF-kB nuclear binding activity and THRB mRNA expression in corresponding animals are represented in Fig. 6B.

\section{Discussion}

The domestic pig is a large animal that closely resembles human TH metabolism (Wassen et al. 2004). In this study, we have shown that pigs have serum levels of $\mathrm{FT}_{4}$ and $\mathrm{FT}_{3}$ similar to that of humans. Characterization of DIOs revealed high DIO1 activity in liver and kidney; DIO2 activity in hypothalamus, pituitary gland, and thyroid gland; and high DIO3 activity in hypothalamus, frontal lobe, pituitary, and adrenal gland. A remarkable difference between pig and human DIO activity was a lack of significant DIO1 enzyme activity in pig thyroid gland; however, our results agree with a previous report in pig (Wassen et al. 2004). Finally, relative gene expression of TH transporter MCT8, THRs, and cofactors has been characterized in all analyzed tissues.

LPS administration induced a profound decrease in serum TH levels resulting in tissue hypothyroidism. The observed decrease in MCT8 expression may also reduce TH supply to those tissues depending on MCT8 for TH transport. Furthermore, the LPS-induced decrease in DIO1 gene expression and enzyme activity in liver and kidney, a common finding in models of NTIS (Bianco et al. 2002, Boelen et al. 2011), contributed to decreased $\mathrm{T}_{3}$ production.

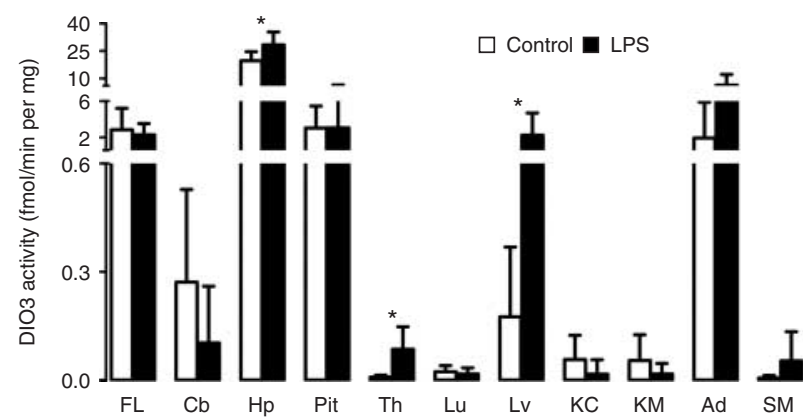

Figure 3

DIO3 activity in tissues from control $(n: 8)$ and LPS (n:9)-treated pigs. DIO3 activity was detected in all studied tissues, although large differences between tissues were observed. LPS administration caused a statistically significant increase in DIO3 activity in liver, hypothalamus, and thyroid gland. Values are represented as mean \pm s.D. $\left({ }^{*} P<0.05\right.$; FL, frontal lobe; $\mathrm{Cb}$, cerebellum; $\mathrm{Hp}$, hypothalamus; Pit, pituitary; Th, thyroid gland; Lu, lung; Lv, liver; KM, kidney medulla; KC, kidney cortex; Ad, adrenal gland; SM, skeletal muscle).

Published by Bioscientifica Ltd 


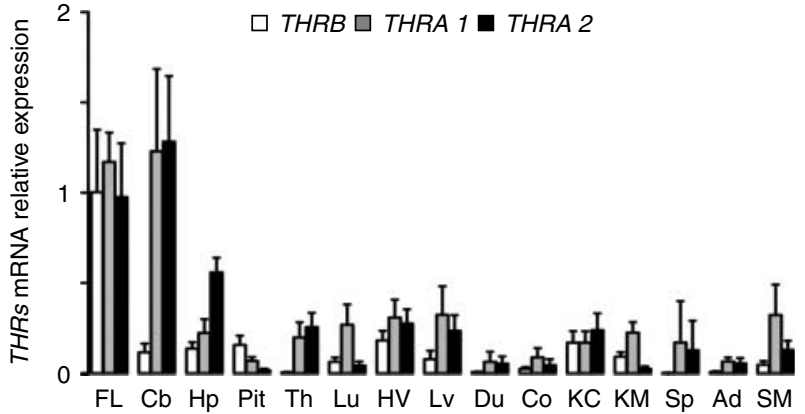

Figure 4

Relative gene expression of THRs in tissues from control pigs ( $n: 8)$. Relative expression of THRB, THRA1, and THRA2 genes calculated using the $2^{-\Delta \Delta} C T$ method are normalized against THRB expression in frontal lobe. RPL4 mRNA expression was used as a reference gene. Values are represented as mean \pm s.D. (FL, frontal lobe; $\mathrm{Cb}$, cerebellum; $\mathrm{Hp}$, hypothalamus; Pit, pituitary; Th, thyroid gland; Lu, lung; HV, heart left ventricle; Lv, liver; Du, duodenum; Co, colon; KC, kidney cortex; KM, kidney medulla; Ad, adrenal gland; SM, skeletal muscle).

LPS infusion stimulated DIO3 activity in several tissues and such an increase promotes conversion of $\mathrm{T}_{4}$ into $\mathrm{rT}_{3}$ and accelerates $\mathrm{T}_{3}$ clearance, contributing to NTIS hypothyroidism (Gereben et al. 2008). NTIS is often associated with elevated serum levels of $\mathrm{rT}_{3}$ as a consequence of an increase in DIO3 activity (Wartofsky \& Burman 1982, DeGroot 1999). However, $\mathrm{rT}_{3}$ levels did not increase in LPS-treated pigs, likely a consequence of the low tissue levels of $\mathrm{T}_{4}$. However, the serum $\mathrm{rT}_{3} / \mathrm{T}_{4}$ ratio did increase after LPS treatment, indicating that increased DIO3 activity was effective, especially when $\mathrm{rT}_{3} / \mathrm{T}_{4}$ ratio is not expected to increase in hypothyroidism due to low levels of $\mathrm{rT}_{3}$ (Burman et al. 1997). The observation that pig liver DIO3 activity increased after LPS agrees with previous studies in critically ill patients (Peeters et al. 2003). However, in mouse models of NTIS, liver DIO3 activity and expression decreased (Boelen et al. 2005, 2008). Also, our finding that DIO3 activity increased in pig hypothalamus after LPS does not agree with studies on rodents that showed no changes in DIO3 activity during prolonged NTIS (Mebis et al. 2009) and a decrease in DIO3 mRNA expression during acute (Boelen et al. 2009) and chronic (Boelen et al. 2006) NTIS. Differences between animal models, study time frame, and severity of inflammatory response may account for differences observed between the pig and rodent models. However, an increase in DIO3 activity in liver and hypothalamus agrees with the reduced levels of $\mathrm{TH}$ observed in these two tissues from humans with NTIS (Arem et al. 1993, Peeters et al. 2003). Interestingly, thyroid gland DIO3 activity increased in LPS-treated pigs and it is tempting to speculate that this might contribute to decreased $\mathrm{T}_{4}$ secretion from the thyroid gland during NTIS.

Hypoxia-inducible factor $1 \alpha$ subunit (HIF-1 $\alpha$ (HIF1A)), a transcription factor that regulates cellular response to hypoxia, has been proposed as an activator
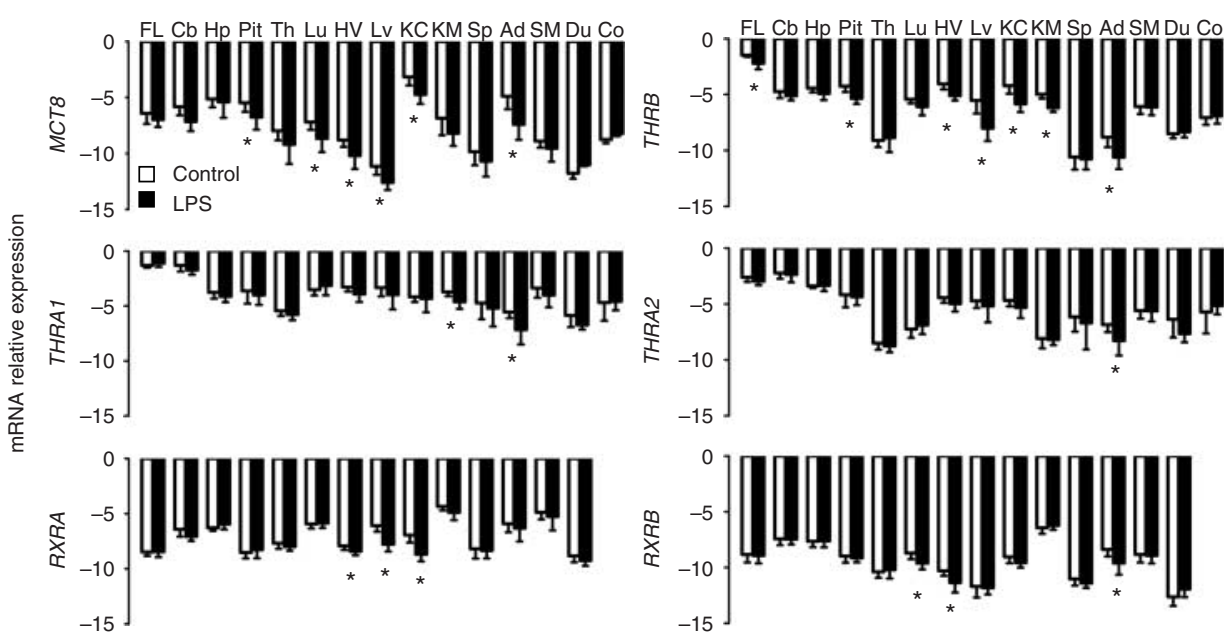

\section{Figure 5}

Monocarboxylate transporter 8 (MCT8); thyroid hormone receptors $\beta$ (THRB), $\alpha 1$ (THRA1), and $\alpha 2$ (THRA2); and retinoid $X$ receptors $\alpha(R X R A)$ and $\beta(R X R B)$ gene expression changes between control $(n: 8)$ and LPS-treated $(\mathrm{n}: 9)$ pigs. Relative gene expression is represented $\Delta C \mathrm{t}$. A $\Delta C \mathrm{t}$ difference of 1 indicates a twofold difference in gene expression. Values are represented
(C) 2013 Society for Endocrinology Printed in Great Britain as mean + s.D. $(* P<0.05 ; \mathrm{FL}$, frontal lobe: $\mathrm{Cb}$, cerebellum; $\mathrm{Hp}$, hypothalamus; Pit, pituitary; Th, thyroid gland; Lu, lung; HV, heart left ventricle; Lv, liver; KC, kidney cortex; KM, kidney medulla; Sp, spleen; Ad, adrenal gland; SM, skeletal muscle; Du, duodenum; Co, colon ( $R X R A$ and $R X R B$ mRNA expression was not measured in colon)). 
AF-kB p65 Ab
NF-kB p50 Ab
NF-kB mutated probe
32P-NF-kB mutated ${ }^{32} \mathrm{P}-\mathrm{NF}-\mathrm{kB}$ consensus

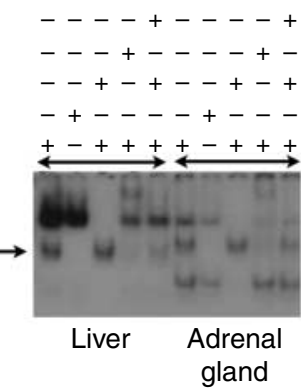

B

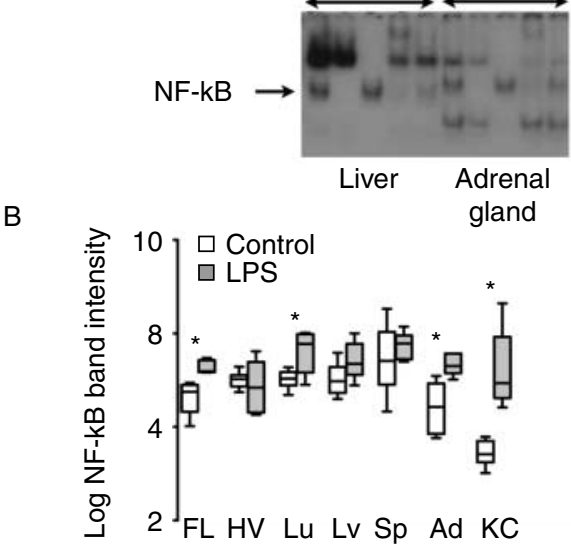

\section{Figure 6}

(A) NF-kB nuclear binding activity in pig tissues evaluated by EMSA. (Left) NF-kB p50-p65 nuclear binding was identified in pig tissues using radioactively labeled oligonucleotides containing a consensus and/or a mutated NF-kB binding site. Non-specific bands were identified using a probe containing a mutated NF-kB binding site in both radiolabeled and non-labeled competition assays (lanes 2, 3, 7, and 8). Specific bands were identified by supershift assays using antibodies against p50 and p65 NF-kB subunits (lanes 4, 5, 9, and 10). (Right upper) Adrenal gland from LPS-treated ( $\mathrm{n}: 6)$ pigs showed higher NF-kB nuclear binding activity than controls $(n: 6)$. (Right lower) Spleen from control $(n: 6)$ pigs had a high basal NF-kB nuclear binding activity that did not increase significantly after LPS (n:6). (B) Relationship between NF-kB nuclear binding (left) and THRB

of DIO3 gene expression and activity (Simonides et al. 2008). It has been hypothesized that under circumstances of cardiac hypoxia, HIF- $1 \alpha$ increases DIO3 activity creating a situation of local hypothyroidism that could reduce oxygen consumption and energy expenditure (Gereben et al. 2008). Although DIO3 activity was not detected in pig heart, in those tissues where LPS induced an increase in DIO3 activity, HIF-1 $\alpha$ gene expression did not increase, and even decreased in the hypothalamus (unpublished data). These findings suggest that the tissue-specific increase in DIO3 activity induced by LPS is not related to increased $H I F-1 \alpha$ gene expression levels.

DIO2 activity was detected in the hypothalamus, pituitary gland, and thyroid gland, and LPS administration did not induce significant changes in DIO2 activity. Previous studies in rats have shown that LPS administration induces $\mathrm{DIO} 2$ activity in mediobasal hypothalamus tanycytes leading to the hypothesis that an increase in hypothalamic DIO2 activity causes a local hyperthyroidism responsible for low TRH mRNA expression in NTIS (Fekete et al. 2004). However, in a

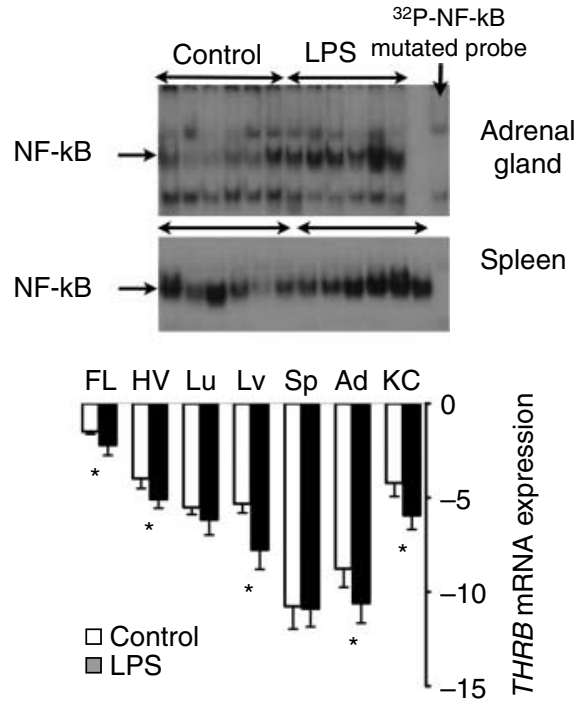

mRNA expression (right) in pig tissues. In frontal lobe (FL), adrenal gland (Ad), and kidney cortex (KC), LPS induced a significant increase in NF-kB nuclear binding activity and a decrease in THRB mRNA expression. In spleen (Sp), no differences in NF-kB nuclear binding or THRB gene expression were observed between groups. In lungs (Lu), LPS caused an increase in NF-kB nuclear binding activity but no change in THRB gene expression was observed between groups. Finally, in heart left ventricle (HV) and liver (Lv), LPS induced a decrease in THRB mRNA expression that did not correspond with a significant increase in NF-kB nuclear binding activity. NF-kB nuclear binding activity is represented with Tukey box-and-whisker plot. THRB mRNA relative expression is represented as $\Delta C \mathrm{t}$ and values as mean \pm s.D. $\left({ }^{*} P<0.05\right)$.

rabbit model of prolonged critical illness, an increase in DIO2 activity or in TH levels was found (Mebis et al. 2009). Moreover, in autopsy samples from humans with severe NTIS, $T_{3}$ concentration decreased in the hypothalamus and pituitary gland (Arem et al. 1993). All together, these results suggest that changes in hypothalamic and pituitary DIO2 activity are not necessary for central hypothyroidism in NTIS.

LPS-treated pigs showed remarkable tissue-specific changes in expression of THRs. Endotoxemic pigs showed decreased levels of $\mathrm{TH}$ and THRB mRNA expression in heart left ventricle, liver, and kidney cortex, while in lung and skeletal muscle TH levels decreased, but no changes in $T H R B$ mRNA expression were observed. These findings suggest that heart, liver, and kidneys of LPS-treated animals are not only hypothyroid but may also have a decreased availability of THR $\beta$. Although quantification of TR $\beta$ protein expression by western blot was attempted, our results were not reliable due to the poor specificity of the commercially available TR $\beta$ antibodies against pig protein; however, in a previous study using tissues from NTIS

Published by Bioscientifica Ltd. 
patients, we showed that decreased THRB mRNA expression levels were associated with decreased protein level (Lado-Abeal et al. 2010).

MCT8 is so far the best-characterized TH transporter. In the brain, MCT8 regulates $\mathrm{T}_{3}$ uptake, and MCT8-null mice show resistance to $\mathrm{TH}$ action in the hypothalamus and pituitary gland (Heuer \& Visser 2009). However, in liver and kidney, MCT8 is not required for TH uptake but plays a role in TH efflux (Liao et al. 2011, Trajkovic-Arsic et al. 2010). MCT8 gene expression decreased in several tissues after LPS administration, although the consequences of such an effect are unknown. Based on the present knowledge, a decrease in pituitary MCT8 expression may aggravate central $\mathrm{TH}$ resistance, especially in the presence of decreased THRB gene expression as observed in LPS-treated pigs. By contrast, LPS-induced decrease in liver and kidney MCT8 mRNA expression should not affect $\mathrm{TH}$ uptake but efflux resulting in an increase in $\mathrm{T}_{3}$ retention. The consequences of LPS-induced inhibition of MCT8 gene expression needs further study.

In frontal lobe cortex, LPS-treated animals had lower $\mathrm{T}_{4}$ than controls, but no differences were observed in $\mathrm{T}_{3}$. These findings are similar to those in pregnant rats near term, where decreased levels of $\mathrm{T}_{4}$ and $\mathrm{T}_{3}$ were observed in all the studied tissues with the exception of the cerebral cortex, which maintained a normal concentration of $\mathrm{T}_{3}$ (Calvo et al. 1990). Normal levels of $\mathrm{T}_{3}$ in the frontal lobe of LPS-treated pigs are difficult to explain because $\mathrm{T}_{4}$ levels were lower than controls, and no differences in DIO3 activity or MCT8 mRNA expression were observed. Also, frontal lobe was among the tissues with the highest level of DIO2 expression, but no enzyme activity was detected. As our experimental design does not allow differentiation of DIO2 activity in a specific subset of brain cells, the mechanisms responsible for sustaining normal $\mathrm{T}_{3}$ levels in frontal lobe after LPS exposure remain unexplained.

Overall, the changes in expression of MCT8 and THRB genes after LPS observed in our study agrees with previous studies on rodent models of NTIS where no changes in hypothalamic expression of MCT8 or THRs have been noticed (Boelen et al. 2006, Mebis et al. 2009), and a decrease in THRB mRNA expression has been reported in the pituitary gland (Boelen et al. 2006), liver (Beigneux et al. 2003), heart (Feingold et al. 2004), and kidney (Feingold et al. 2008). LPS induced a decrease in $R X R A$ in rodent liver (Beigneux et al. 2000), which was also observed in our pig model. The mechanism behind the tissue-specific inhibition of THRs and transporters remains unknown.

Based on our results, it seems reasonable to hypothesize that $\mathrm{TH}$ replacement in animals with LPS-induced
NTIS will normalize thyroid homeostasis in some but not all tissues. Specifically, those organs with decreased expression of MCT8, THRs, and/or increased DIO3 activity may have a decreased sensitivity to TH. The described situation would be more severe in heart left ventricle, liver, adrenal gland, and kidney, where gene expression of $R X R$ s is also decreased.

LPS activates the innate immune response and induces the release of pro-inflammatory cytokines in pigs (Williams et al. 2009). LPS and inflammatory cytokines activate NF-kB, a family of transcription factors central to activation of the immune response (Oeckinghaus et al. 2011). NF-kB activation inhibits the induction of DIO1 and other positively regulated $\mathrm{T}_{3}$-responsive genes by $\mathrm{T}_{3}$ in vitro, an observation that leads to the hypothesis that activation of NF-kB plays a key role in NTIS pathogenesis (Nagaya et al. 2000). In this study, we observed that LPS-induced septic shock was associated with an increase in NF-kB nuclear binding activity in some but not all analyzed tissues. In spleen, liver, and heart left ventricle, no increase in NF-kB nuclear binding activity was observed. In spleen, control pigs had a high basal NF-kB nuclear binding activity that could be caused by the elevated number of resident immune cells continuously exposed to antigens; under such circumstances, LPS-induced NF-kB activation could be more difficult to observe. The findings in liver and heart left ventricle are more difficult to explain. The liver results could be related to lack of statistical power as there was a clear trend toward an increase in NF-kB nuclear binding activity in the LPS-treated group. The absence of significant NF-kB activation in heart left ventricle after LPS administration is intricate. Septic shock causes high mortality in part due to myocardial depression (Parrillo et al. 1990) through mechanisms triggered by pro-inflammatory cytokine-induced high levels of nitric oxide and reactive oxygen species (Finkel et al. 1992, Yokoyama et al. 1993, Goldhaber et al. 1996). Although pro-inflammatory cytokines are mostly released by stimulated circulating immune cells, it has been shown in vitro that LPS induces the release of inflammatory cytokines by myocardial cells through the activation of NF-kB, causing a decrease in cardiomyocyte contractility (Boyd et al. 2006). However, a similar conclusion in pigs cannot be made from our study because NF-kB nuclear binding activity in control pigs' myocardium was not different from activity in myocardium from septic shock pigs, which was remarkably low in both experimental groups. Although the observed discrepancies could be due to different animal models (rodents vs pigs) and experimental design (in vivo vs

Published by Bioscientifica Ltd. 
in vitro), our study was not designed to investigate the role of NF-kB activation in myocardial depression during sepsis.

Our results showed a relationship between increased NF-kB nuclear binding activity and decreased THRB mRNA expression after LPS in some but not all studied tissues. THRB mRNA in the heart and liver decreases despite there being no activation of NF-kB, indicating that NF-kB pathway activation is not solely responsible for the decreased expression of THRB. There are several possible mechanisms that could be responsible for the observed decrease in THRB gene expression, including other inflammatory pathways, epigenetic changes, or increased mRNA degradation. Additionally, the THRB gene has multiple transcription start sites (Franton et al. 2004), which raises the possibility that multiple promoter regions regulate $T H R B$ gene expression. Under these circumstances, tissue-specific expression of THRB could be regulated by the use of different promoters resulting in a tissue-specific gene expression profile. As THRB gene expression was not affected by NF-kB activation in the lung, it is possible that THRB gene transcription in the lung is regulated differently from THRB gene transcription in the frontal lobe, adrenal, and kidney cortex, which showed a decrease in THRB gene expression and an increase in NF-kB nuclear binding activity. Participation of the NF-kB pathway in regulating THRB mRNA in frontal lobe, adrenal gland, and kidney cortex cannot be excluded based on these results; however, an alternate mechanism must be responsible for the decrease in THRB expression in heart, liver, and lung. Further studies are needed to identify the different pig THRB promoters and the potential regulation by NF-kB.

This study has several limitations. Food intake decreased in LPS-treated pigs, indicating that most food present in these animals' gastrointestinal system resulted mostly from intake before LPS administration. As no nutritional support was provided, the effect of low energy intake on observed changes cannot be quantified. Our model describes changes occurring early in a severe form of NTIS associated with high mortality during the first $24 \mathrm{~h}$ of LPS infusion. In previous studies, we treated pigs with lower doses of LPS and, in spite of the fact that all animals presented fever, NTIS phenotype was not observed, indicating that in pigs treated with LPS there is a narrow margin between absence of NTIS phenotype and presence of severe septic shock. Nowadays, fulminant cases of septic shock are uncommon in clinical settings and consequences of $\mathrm{TH}$ replacement in such situations would probably be difficult to assess. A pig model of LPS-induced septic shock NTIS with airway, hemodynamic, and nutritional support as in hospital intensive care units will provide more practical information for human NTIS pathophysiology in clinical settings.

In conclusion, LPS-induced septic shock NTIS in pigs caused a severe hypothyroidism with decreased levels of THs in tissues. Conditions for reduced sensitivity to $\mathrm{TH}$ action are also observed in some tissues. LPS-induced NF-kB nuclear binding activity was present in most but not all the analyzed tissues and, overall, a relationship between NF-kB activation and decrease in THRB gene expression was not observed.

\section{Declaration of interest}

The authors declare that there is no conflict of interest that could be perceived as prejudicing the impartiality of the research reported.

\section{Funding}

This work was supported by the $\mathrm{CH}$ Foundation (to J L-A), Spanish Ministerio de Educación (grant SAF2006-02542 to J L-A, grant SAF2009-09364 to M-J O), and Comunidad de Madrid (grant S2010BMD-2423 to M-J O).

\section{Author contribution statement}

I $C$ and $L Q$ have contributed equally to the manuscript and should be given equal consideration. They participated in the animals study and performed most of the molecular studies. R-M C and M-J O measured the tissue hormonal levels. M-J O participated in drafting the manuscript and provided research funds. J L-A designed the study, performed the animals' surgery, collected the tissues, draft the manuscript, and provided most of the research funds. He is the research Principal investigator. All the authors participated in the manuscript discussion.

\section{Acknowledgements}

The authors would like to thank Dr J McGlone, Department of Animal and Food Sciences, Texas Tech University, for his advice with pig surgery. They also thank Dr RL Norman, Department of Pharmacology and Neurosciences, and Dr J Hutson, Department of Cell Biology and Biochemistry, Texas Tech University Health Sciences Center, for their advice with DIO3 assays and Dr D Araujo, Department of Internal Medicine, and Dr S Lojo, Clinical Biochemistry Laboratory, Complejo Hospitalario Universitario de Santiago (CHUS), University of Santiago de Compostela, Spain, for their assistance with serum hormone measurement.

\section{References}

Arem R, Wiener GJ, Kaplan SG, Kim HS, Reichlin S \& Kaplan MM 1993 Reduced tissue thyroid hormone levels in fatal illness. Metabolism 42 1102-1108. (doi:10.1016/0026-0495(93)90266-Q)

Beigneux AP, Moser AH, Shigenaga JK, Grunfeld C \& Feingold KR 2000 The acute phase response is associated with retinoid $\mathrm{X}$ receptor repression in rodent liver. Journal of Biological Chemistry 275 16390-16399. (doi:10.1074/jbc.M000953200) 
Beigneux AP, Moser AH, Shigenaga JK, Grunfeld C \& Feingold KR 2003 Sick euthyroid syndrome is associated with decreased TR expression and DNA binding in mouse liver. American Journal of Physiology. Endocrinology and Metabolism 284 E228-E236.

Bianco AC, Salvatore D, Gerenben B, Berry MJ \& Larsen PR 2002 Biochemistry, cellular and molecular biology, and physiological roles of the iodothyronine selenodiodinases. Endocrine Reviews 23 38-89. (doi:10.1210/er.23.1.38)

Boelen A, Kwakkel J, Alkemade A, Renckens R, Kaptein E, Kuiper G, Wiersinga WM \& Visser TJ 2005 Induction of type 3 deiodinase activity in inflammatory cells of mice with chronic local inflammation. Endocrinology 146 5128-5134. (doi:10.1210/en.2005-0608)

Boelen A, Kwakkel J, Wiersinga WM \& Fliers E 2006 Chronic local inflammation in mice results in decreased TRH and type 3 deiodinase mRNA expression in the hypothalamic paraventricular nucleus independently of diminished food intake. Journal of Endocrinology 191 707-714. (doi:10.1677/joe.1.07056)

Boelen A, Boorsma J, Kwakkel J, Wieland CW, Renckens R, Visser TJ, Fliers E \& Wiersinga WM 2008 Type 3 deiodinase is highly expressed in infiltrating neutrophilic granulocytes in response to acute bacterial infection. Thyroid 18 1095-1103. (doi:10.1089/thy.2008.0090)

Boelen A, Kwakkel J, Chassande O \& Fliers E 2009 Thyroid hormone receptor $\beta$ mediates acute illness-induced alterations in central thyroid hormone metabolism. Journal of Neuroendocrinology $21465-472$ (doi:10.1111/j.1365-2826.2009.01863.x)

Boelen A, Kwakkel J \& Fliers E 2011 Beyond low plasma $\mathrm{T}_{3}$ : local thyroid hormone metabolism during inflammation and infection. Endocrine Reviews 32 670-693. (doi:10.1210/er.2011-0007)

Boelen A, van Beeren M, Vos X, Surovtseva O, Belegri E, Saaltink D-J, Vreugdenhil E, Kalsbeek A, Kwakkel J \& Fliers E 2012 Leptin administration restores the fasting-induced increase of hepatic type 3 deiodinase expression in mice. Thyroid 22 192-199. (doi:10.1089/thy. 2011.0289)

Boyd JH, Mathur S, Wang Y, Bateman RM \& Walley KR 2006 Toll-like receptor stimulation in cardiomyocites decreases contractility and initiates an NF-kB dependent inflammatory response. Cardiovascular Research 72 384-393. (doi:10.1016/j.cardiores.2006.09.011)

Burman KD, Dimond RC, Wright FD, Earll JM, Bruton J \& Wartofsky L 1997 A radioimmunoassay for $3,3^{\prime}, 5^{\prime}$-L-triiodothyronine (reverse $T_{3}$ ): assessment of thyroid gland content and serum measurements in conditions of normal and altered thyroidal economy and following administration of thyrotropin releasing hormone (TRH) and thyrotropin (TSH). Journal of Clinical Endocrinology and Metabolism 44 660-672. (doi:10.1210/jcem-44-4-660)

Calvo R, Obregon J, Ruiz de Oña C, Ferreiro B, Escobar del Rey F \& Morreale de Escobar G 1990 Thyroid hormone economy in pregnant rats near term: a "physiological" animal model of nonthyroidal illness syndrome? Endocrinology 127 10-16. (doi:10.1210/endo-127-1-10)

Calvo R, Morreale de Escobar G, Escobar del Rey F \& Obregón MJ 1997 Maternal nonthyroidal illness and fetal thyroid hormone status, as studied in the streptozotocin-induced diabetes mellitus rat model. Endocrinology 138 1159-1169. (doi:10.1210/en.138.3.1159)

Debaveye Y, Ellger B, Mebis L, Van Herck E, Coopmans W, Darras V \& Van den Berghe G 2005 Tissue deiodinase activity during prolonged critical illness: effects of exogenous thyrotropin-releasing hormone and its combination with growth hormone-releasing peptide-2 Endocrinology 146 5604-5611. (doi:10.1210/en.2005-0963)

DeGroot LJ 1999 Dangerous dogmas in medicine: the nonthyroidal illness syndrome. Journal of Clinical Endocrinology and Metabolism 84 151-164. (doi:10.1210/jc.84.1.151)

DeGroot LJ 2003 "Non-thyroidal illness syndrome" is a functional central hypothyroidism, and if severe, hormone replacement is appropriate in light of present knowledge. Journal of Endocrinological Investigation 26 $1163-1170$

Dumitrescu AM, Liao XH, Abdullah MS, Lado-Abeal J, Majed FA, Moeller LC, Boran G, Schomburg L, Weiss RE \& Refetoff S 2005 Mutations in
SECISBP2 result in abnormal thyroid hormone metabolism. Nature Genetics 37 1247-1252. (doi:10.1038/ng1654)

Feingold K, Kim MS, Shigenaga J, Moser A \& Grunfeld C 2004 Altered expression of nuclear hormone receptors and coactivators in mouse heart during the acute-phase response. American Journal of Physiology Endocrinology and Metabolism 286 E201-E207. (doi:10.1152/ajpendo. 00205.2003)

Feingold KR, Wang Y, Moser A, Shigenaga JK \& Grunfeld C 2008 LPS decreases fatty acid oxidation and nuclear hormone receptors in the kidney. Journal of Lipid Research 49 2179-2187. (doi:10.1194/jlr. M800233-JLR200)

Fekete C, Gereben B, Doleschall M, Harney JW, Dora JM, Bianco AC, Sarkar S Liposits Z, Rand W, Emerson C et al. 2004 Lipopolysaccharide induces type 2 iodothyronine deiodinase in the mediobasal hypothalamus: implications for the nonthyroidal illness syndrome. Endocrinology 145 1649-1655. (doi:10.1210/en.2003-1439)

Finkel MS, Oddis CV, Jacob TD, Watkins SC, Hattler BG \& Simmons RL 1992 Negative inotropic effects of cytokines on the heart mediated by nitric oxide. Science 257 387-389. (doi:10.1126/science.1631560)

Fliers E, Guldenaar SE, Wiersinga WM \& Swaab DF 1997 Decreased hypothalamic thyrotropin-releasing hormone gene expression in patients with nonthyroidal illness. Journal of Clinical Endocrinology and Metabolism 82 4032-4036. (doi:10.1210/jc.82.12.4032)

Franton S, Harvey CB, Gleason LM, Fadel A \& Williams GR 2004 Multiple messenger ribonucleic acid variants regulate cell-specific expression of human thyroid hormone receptor beta1. Molecular Endocrinology 18 1631-1642. (doi:10.1210/me.2003-0346)

Gereben B, Zavacki AM, Ribich S, Kim BW, Huang SA, Simonides WS, Zeöld A \& Bianco AC 2008 Cellular and molecular basis of deiodinaseregulated thyroid hormone signaling. Endocrine Reviews 29 898-938. (doi:10.1210/er.2008-0019)

Goldhaber JI, Kim KH, Natterson PD, Lawrence T, Yang P \& Weiss JN 1996 Effects of TNF-alpha on $\left[\mathrm{Ca}^{2+}\right]_{\mathrm{i}}$ and contractility in isolated adult rabbit ventricular myocytes. American Journal of Physiology 271 H1449-H1455.

van Haasteren GA, van der Meer MJ, Hermus AR, Linkels E, Klootwijk W, Kaptein E, van Toor H, Sweep CG, Visser TJ \& de Greef WJ 1994 Different effects of continuous infusion of interleukin-1 and interleukin-6 on the hypothalamic-hypophysial-thyroid axis. Endocrinology 135 1336-1345. (doi:10.1210/en.135.4.1336)

Heuer H \& Visser TJ 2009 Pathophysiological importance of thyroid hormone transporters. Endocrinology 150 1078-1083. (doi:10.1210/ en.2008-1518)

Jakobs TC, Mentrup B, Schmutzler C, Dreher I \& Kohrle J 2002 Proinflammatory cytokines inhibit the expression and function of human type I 5'-deiodinase in HepG2 hepatocarcinoma cells. European Journal of Endocrinology 146 559-566. (doi:10.1530/eje.0.1460559)

Kwakkel J, Wiersinga WM \& Boelen A 2006 Differential involvement of nuclear factor-kappaB and activator protein-1 pathways in the interleukin-1 $\beta$-mediated decrease of deiodinase type 1 and thyroid hormone receptor $\beta 1$ mRNA. Journal of Endocrinology 189 37-44. (doi:10.1677/joe.1.06354)

Lado-Abeal J, Dumitrescu AM, Liao XH, Cohen RN, Pohlenz J, Weiss RE, Lebrethon MC, Verloes A \& Refetoff S 2005 A de novo mutation in an already mutant nucleotide of the thyroid hormone receptor beta gene perpetuates resistance to thyroid hormone. Journal of Clinical Endocrinology and Metabolism 90 1760-1767. (doi:10.1210/jc.2004-1488)

Lado-Abeal J, Romero A, Castro-Piedras I, Rodriguez-Perez A \& AlvarezEscudero J 2010 Thyroid hormone receptors are down-regulated in skeletal muscle of patients with non-thyroidal illness syndrome secondary to non-septic shock. European Journal of Endocrinology 163 765-773. (doi:10.1530/EJE-10-0376)

Legradi G, Emerson CH, Ahima RS, Flier JS \& Lechan RM 1997 Leptin prevents fasting-induced suppression of prothyrotropin- releasing hormone messenger ribonucleic acid in neurons of the hypothalamic paraventricular nucleus. Endocrinology 138 2569-2576. (doi:10.1210/ en.138.6.2569) 
Liao XH, Di Cosmo C, Dumitrescu AM, Hernandez A, van Sande J, St Germain DL, Weiss RE, Galton VA \& Refetoff S 2011 Distinct roles of deiodinases on the phenotype of Mct8 defect: a comparison of eight different mouse genotypes. Endocrinology 152 1180-1191. (doi:10.1210/en.2010-0900)

Livak KJ \& Schmittgen TD 2011 Analysis of relative gene expression data using real-time quantitative PCR and the $2^{-\Delta \Delta}$ CT method. Methods $\mathbf{2 5}$ 402-408. (doi:10.1006/meth.2001.1262)

Mebis L, Debaveye Y, Ellger B, Derde S, Ververs EJ, Langouche L, Darras VM, Fliers E, Visser TJ \& Van den Berghe G 2009 Changes in the central component of the hypothalamus-pituitary-thyroid axis in a rabbit model of prolonged critical illness. Critical Care 13 R147. (doi:10.1186/ cc8043)

Morreale de Escobar G, Pastor R, Obregon MJ \& Escobar del Rey F 1985 Effects of maternal hypothyroidism on the weight and thyroid hormone content of rat embryonic tissues, before and after onset of fetal thyroid function. Endocrinology 117 1890-1900. (doi:10.1210/ endo-117-5-1890)

Nagaya T, Fujieda M, Otsuka G, Yang JP, Okamoto T \& Seo H 2000 A potential role for activated NF-kappa B in the pathogenesis of euthyroid sick syndrome. Journal of Clinical Investigation 106 393-402.

Oeckinghaus A, Hayden MS \& Ghosh S 2011 Crosstalk in NF-kB signaling pathways. Nature Immunology 12 695-708. (doi:10.1038/ni.2065)

O'Mara BA, Dittrich W, Lauterio TJ \& St Germain DL 1993 Pretranslational regulation of type I $5^{\prime}$-deiodinase by thyroid hormones and in fasted and diabetic rats. Endocrinology 133 1715-1723. (doi:10.1210/ en.133.4.1715)

Parrillo JE, Parker MM, Natanson C, Suffredini AF, Danner RL, Cunnion RE \& Ognibene FP 1990 Septic shock in humans. Advances in the understanding of pathogenesis, cardiovascular dysfunction, and therapy. Annals of Internal Medicine 113 227-242.

Peeters RP, Wouters PJ, Kaptein E, Van Toor H, Visser TJ \& Van den Berghe G 2003 Reduced activation and increased inactivation of thyroid hormone in tissues of critically ill patients. Journal of Clinical Endocrinology and Metabolism 88 3202-3211. (doi:10.1210/jc.2002-022013)

Rodriguez-Perez A, Palos-Paz F, Kaptein E, Visser TJ, Dominguez-Gerpe L, Alvarez-Escudero J \& Lado-Abeal J 2008 Identification of molecular mechanisms related to nonthyroidal illness syndrome in skeletal muscle and adipose tissue from patients with septic shock. Clinical Endocrinology 68 821-827. (doi:10.1111/j.1365-2265.2007.03102.x)

Ruiz de Oña C, Morreale de Escobar G, Calvo R, Escobar del Rey F \& Obregón MJ 1991 Thyroid hormones and 5'-deiodinase in the rat fetus late in gestation: effects of maternal hypothyroidism. Endocrinology 128 422-432. (doi:10.1210/endo-128-1-422)
Silva JE 2006 Thermogenic mechanisms and their hormonal regulation. Physiological Reviews 86 435-464. (doi:10.1152/physrev.00009.2005) Simonides WS, Mulcahey MA, Redout EM, Muller A, Zuidwijk MJ, Visser TJ, Wassen FW, Crescenzi A, da-Silva WS, Harney J et al. 2008 Hypoxiainducible factor induces local thyroid hormone inactivation during hypoxic-ischemic disease in rats. Journal of Clinical Investigation 118 975-983.

Slag MF, Morley JE, Elson MK, Crowson TW, Nuttall FQ \& Shafer RB 1981 Hypothyroxinemia in critically ill patients as a predictor of high mortality. Journal of the American Medical Association 245 43-45. (doi:10.1001/jama.1981.03310260021020)

Stathatos N \& Wartofsky L 2003 The euthyroid sick syndrome: is there a physiological rationale for thyroid hormone treatment? Journal of Endocrinological Investigation 26 1174-1179.

Trajkovic-Arsic M, Visser TJ, Darras VM, Friesema EC, Schlott B, Mittag J, Bauer K \& Heuer H 2010 Consequences of monocarboxylate transporter 8 deficiency for renal transport and metabolism of thyroid hormones in mice. Endocrinology 151 802-809. (doi:10.1210/ en.2009-1053)

Van den Berghe G, de Zegher F, Baxter RC, Veldhuis JD, Wouters P, Schetz M, Verwaest C, Van der Vorst E, Lauwers P, Bouillon R et al. 1998 Neuroendocrinology of prolonged critical illness: effects of exogenous thyrotropin-releasing hormone and its combination with growth hormone secretagogues. Journal of Clinical Endocrinology and Metabolism 83 309-319. (doi:10.1210/jc.83.2.309)

Wartofsky L \& Burman KD 1982 Alterations in thyroid function in patients with systemic illness: the 'euthyroid sick syndrome'. Endocrine Reviews 3 164-203. (doi:10.1210/edrv-3-2-164)

Wassen FWJS, Klootwijk W, Kaptein E, Duncker DJ, Visser TJ \& Kuiper GGJM 2004 Characteristics and thyroid state-dependent regulation of iodothyronine deiodinases in pigs. Endocrinology 145 4251-4263. (doi:10.1210/en.2004-0356)

Williams PN, Collier CT, Carroll JA, Welsh TH \& Laurenz JC 2009 Temporal pattern and effect of sex on lipopolysaccharide-induced stress hormone and cytokine response in pigs. Domestic Animal Endocrinology 37 139-147. (doi:10.1016/j.domaniend.2009.04.004)

Yokoyama T, Vaca L, Rossen RD, Durante W, Hazarika P \& Mann DL 1993 Cellular basis for the negative inotropic effects of tumor necrosis factoralpha in the adult mammalian heart. Journal of Clinical Investigation 92 2303-2312. (doi:10.1172/JCI116834)

Yu J \& Koenig RJ 2000 Regulation of hepatocyte thyroxine 5'-deiodinase by $\mathrm{T}_{3}$ and nuclear receptor coactivators as a model of the sick euthyroid syndrome. Journal of Biological Chemistry 275 38296-38301. (doi:10.1074/jbc.M004866200)

Received in final form 15 December 2012

Accepted 7 January 2013

Accepted Preprint published online 7 January 2013 http://jme.endocrinology-journals.org DOI: 10.1530/JME-12-0188
(ㄷ) 2013 Society for Endocrinology Printed in Great Britain
Published by Bioscientifica Ltd. 